\title{
ULOGA ŽELJEZNIČKOG PROMETA U RIJECI KAO CENTRU POVIJESNE, KULTURNE I PROMETNE RAZLIČITOSTI I POVEZANOSTI
}

\author{
Sanja Paić i Dražen Kaužljar \\ Safety.guru INSTITUT za promicanje kulture i sigurnosti u prometu \\ Pavla Lončara 12, 10360 Zagreb \\ e-mail: institute.safety.guru@gmail.com
}

Sažetak

S aspekta sigurnosti željezničkog prometa tehnička razina sigurnosti i osposobljenost željezničkih radnika na visokoj je razini. Analize izvanrednih dogadaja u željezničkom prometu pokazuju kako najveći broj ozbiljnih nesreća prouzroče druge osobe. To su osobe koje nisu izravno povezane sa željezničkim prometom poput putnika ili željezničara. Već desecima godina u Hrvatskoj se provode različite preventivne akcije usmjerene prema drugim osobama kao što je akcija „Vlak je uvijek brži“. Povremeno su preventivne akcije željezničkih poduzeća u vezi s dogadajima izvan željezničkog sustava. Jedan od takvih je i promoviranje Rijeke kao Europske prijestolnice kulture u 2020. Grad Rijeka centar je povijesne, kulturne, ali i prometne razlicitosti i povezanosti. Prometna povezanost odnosi se na Luku Rijeku i Mediteranski koridor. Taj jednogodišnji dogadaj bila je izvrsna prilika za podizanje razine sigurnosti i kulture u željezničkom prometu. Temeljem navedenog teza koja je postavljena u radu je da se urbana, umjetnička intervencija na željezničkim objektima u Rijeci može temeljiti na suvremenim smjernicama društveno odgovornog poslovanja i održivog razvoja. U prvom redu bilo je potrebno napraviti analizu stanja željezničkih objekata na kojima je moguće provoditi urbanu umjetničku intervenciju. To su željeznički mostovi, željezničko-cestovni i pješački prijelazi, željezničke ograde, željeznička pruga i druge zgrade. Metodom promatranja i fotografiranja postojećeg stanja izradena je podloga za sinteze stečenih informacija i znanja. Očekivani je rezultat rada utvrdivanje i provodenje preventivnih akcija na željezničkom području u Rijeci te smanjenje broja izvanrednih dogadaja.

Ključne riječi: Europska prijestolnica kulture, urbana intervencija, prometna dostupnost, Grad Rijeka, željezničko cestovni prijelazi

\section{UVOD}

Sigurnost prometa prioritet je u svim vrstama prometa, a u željezničkom prometu regulirana je zasebnim zakonom i podzakonskim aktima. Posebna pozornost sigurnosti željezničkog prometa posvetila se nakon podjele jedinstvenog željezničkog sustava na upravitelja infrastrukture i željezničke prijevoznike. Prioritet je bio zadržati visoku razinu sigurnosti i dalje je unaprjeđivati. Danas se može reći kako je s aspekta sigurnosti željezničkog prometa tehnička razina sigurnosti i osposobljenost željezničkih radnika na visokoj razini. Godišnja izvješća o sigurnosti željezničkog prometa i analize izvanrednih događaja u željezničkom prometu pokazuju kako najveći broj ozbiljnih nesreća prouzro- 
če treće osobe. Ozbiljne nesreće izvanredni su događaji s najtežim posljedicama, a treće su osobe one koje nisu izravno povezane sa željezničkim prometom poput putnika ili željezničara. Ta je statistika logična stoga što su treće osobe najmanje upoznate sa željezničkim prometom i opasnostima za život i zdravlje.

Željeznička poduzeća u cijelom svijetu pa tako i u Republici Hrvatskoj (RH) provode različite preventivne akcije kako bi se educiralo i osvijestilo sve sudionike o opasnostima u prometu. Najveća pozornost usmjerava se prema korisnicima željezničko-cestovnih prijelaza (ŽCP) te učenicima osnovnih i srednjih škola. Već desecima godina prepoznatljiva je akcija „Vlak je uvijek brži“. Preventivne aktivnosti „Vlak je uvijek brži“ održavaju se na ŽCP-ima s većim brojem izvanrednih događaja, ali se povremeno održavaju izvan područja željezničke infrastrukture ili su u vezi s događajima izvan željezničkog sustava. Područja izvan željezničke infrastrukture najčešće su osnovne i srednje škole. To su najljepši trenuci preventivnih akcija jer se educira mlade, ali se i od njih dobiju inspirativne ideje i najtopliji dojmovi. Najveći događaj po pitanju preventivnih akcija u željezničkom prometu koji je organizirala HŽ Infrastruktura d.o.o. u suradnji s Fakultetom prometnih znanosti iz Zagreba bila je „10. Međunarodna konferencija International Level Crossing Awareness Day (ILCAD)“, odnosno Međunarodni dan svjesnosti o opasnostima na ŽCP-ima. Taj događaj bio je pokazatelj kako se i u budućnosti trebaju organizirati različiti događaji kojima se preventivno djeluje na unaprjeđenje sigurnosti željezničkog prometa.

Jedan od takvih događaja mogao bi biti jednogodišnja aktivnost u Rijeci kao „Europskoj prijestolnici kulture“. Grad Rijeka je „Europska prijestolnica kulture“ u 2020. godini. Titula je gradu Rijeci dodijeljena za program „Luka različitosti“. Grad Rijeka centar je povijesne, kulturne, ali i prometne različitosti i povezanosti. Prometna povezanost odnosi se na Luku Rijeku i Mediteranski koridor. Taj jednogodišnji događaj bila je izvrsna prilika za podizanje razine sigurnosti i kulture u željezničkom prometu.

Kako bi se željeznička poduzeća aktivno uključila s preventivnim akcijama na području grada Rijeke tijekom 2020. godine, u prvom redu bilo je potrebno napraviti analizu stanja željezničkih objekata na kojima je moguće provoditi urbanu umjetničku intervenciju. To su bili željeznički mostovi, ŽCP-i i željezničko-pješački prijelazi (ŽPP), željezničke ograde, željeznička pruga i druge zgrade. Metodom promatranja i fotografiranja postojećeg stanja prikupljeni su podaci za analizu provedenu u ovom radu koji su poslužili za sintezu stečenih informacija i znanja u cilju pokretanja preventivnih akcija. Realizacija preventivnih akcija tijekom 2020. godine izostala je zbog pandemije koronavirusa. Stečena znanja ipak ostaju i trebaju se koristiti u sljedećim godinama kad će to epidemiološka situacija dopuštati.

\section{PREGLED STATISTIČKIH POKAZATELJA O IZVANREDNIM DOGAĐAJIMA U ŽELJEZNIČKOM PROMETU}

Istraživanje željezničkih nesreća, odnosno podjela izvanrednih događaja u željezničkom prometu regulirana je Zakonom o sigurnosti i interoperabilnosti željezničkog sustava (NN 63/20) koji u željezničkom prometu razlikuje: 
- ozbiljnu nesreću - sudar vlakova ili iskliznuće vlaka koje ima za posljedicu smrt najmanje jedne osobe ili teške ozljede pet ili više osoba ili veliku štetu na vozilima, željezničkoj infrastrukturi ili okolišu, kao i svaka druga slična nesreća s očiglednim utjecajem na sigurnost željezničkog sustava ili na upravljanje sigurnošću; velika šteta je šteta koju Istražno tijelo može odmah procijeniti najmanje na ukupnu kunsku protuvrijednost od 2 milijuna eura;

- nesreću - neželjeni ili nenamjerni iznenadni događaj ili slijed takvih događaja koji ima štetne posljedice, a koji može biti sudar, iskliznuće, nesreća na željezničko-cestovnom prijelazu i pješačkom prijelazu preko pruge, nesreća s ljudskim žrtvama uzrokovana vozilom u pokretu, požar i drugo; i

- incident - svaki događaj, osim nesreće ili ozbiljne nesreće, povezan s odvijanjem željezničkog prometa koji utječe na sigurnost željezničkog sustava.

Analize izvanrednih događaja rade se prema vrstama, uzrocima i posljedicama.

\subsection{Pregled izvanrednih dogadaja u željezničkom prometu prema vrstama}

Svako željezničko poduzeće radi analizu izvanrednih događaja koja se dostavlja Agenciji za sigurnost željezničkog prometa. U tradicionalnom željezničkom sustavu tu analizu radilo je jedino poduzeće - HŽ Infrastruktura d.o.o. Danas najveći dio istraga izvanrednih događaja organizira $\mathrm{HZZ} \mathrm{Infrastruktura} \mathrm{d.o.o.} \mathrm{pa} \mathrm{samim} \mathrm{tim} \mathrm{izrađuje} \mathrm{i} \mathrm{analize.} \mathrm{U}$ Tablici 1 prikazan je udjel izvanrednih događaja po vrstama i godinama.

Tablica 1. Udjel izvanrednih dogadaja u željezničkom prometu po vrstama i godinama (\%)

\begin{tabular}{|l|c|c|c|c|c|c|}
\hline \multicolumn{1}{|c|}{ Kategorija } & $\mathbf{2 0 1 4 .}$ & $\mathbf{2 0 1 5 .}$ & $\mathbf{2 0 1 6 .}$ & $\mathbf{2 0 1 7 .}$ & $\mathbf{2 0 1 8 .}$ & $\mathbf{2 0 1 9 .}$ \\
\hline Ozbiljne nesreće & 1,6 & 1,3 & 1,4 & 1,9 & 2,1 & 1,5 \\
\hline Nesreće & 9,1 & 7,1 & 7,2 & 6,0 & 6,3 & 8,5 \\
\hline Incidenti & 89,3 & 91,6 & 91,5 & 92,0 & 91,6 & 90,0 \\
\hline Ukupno: & 100,0 & 100,0 & 100,0 & 100,0 & 100,0 & 100,0 \\
\hline
\end{tabular}

Izvor: HŽ Infrastruktura, 2020a (Izradili autori)

U Tablici 1 vidljivo je kako ozbiljne nesreće kao najteži izvanredni događaji sudjeluju ukupno s 1,3 do 2,1\%. Nesreće koje također obuhvaćaju ozljede ljudi sudjeluju sa 6,0 do $9,1 \%$ u zadnjih šest godina. Željeznička poduzeća svake godine postavljaju ciljeve kako bi se sustavno smanjivao broj ozbiljnih nesreća i nesreća, a opći cilj je postići $0 \%$ ozbiljnih nesreća u željezničkom prometu.

Incidenti su prva upozorenja prije nekih težih oblika izvanrednih događaja i zbog toga se u željezničkim poduzećima pozornost posvećuje incidentima kojih prosječno godišsnje bude od 89,3 do 92\%, odnosno 9/10 ukupnog broja izvanrednih događaja kao što se vidi na Slici 1. 


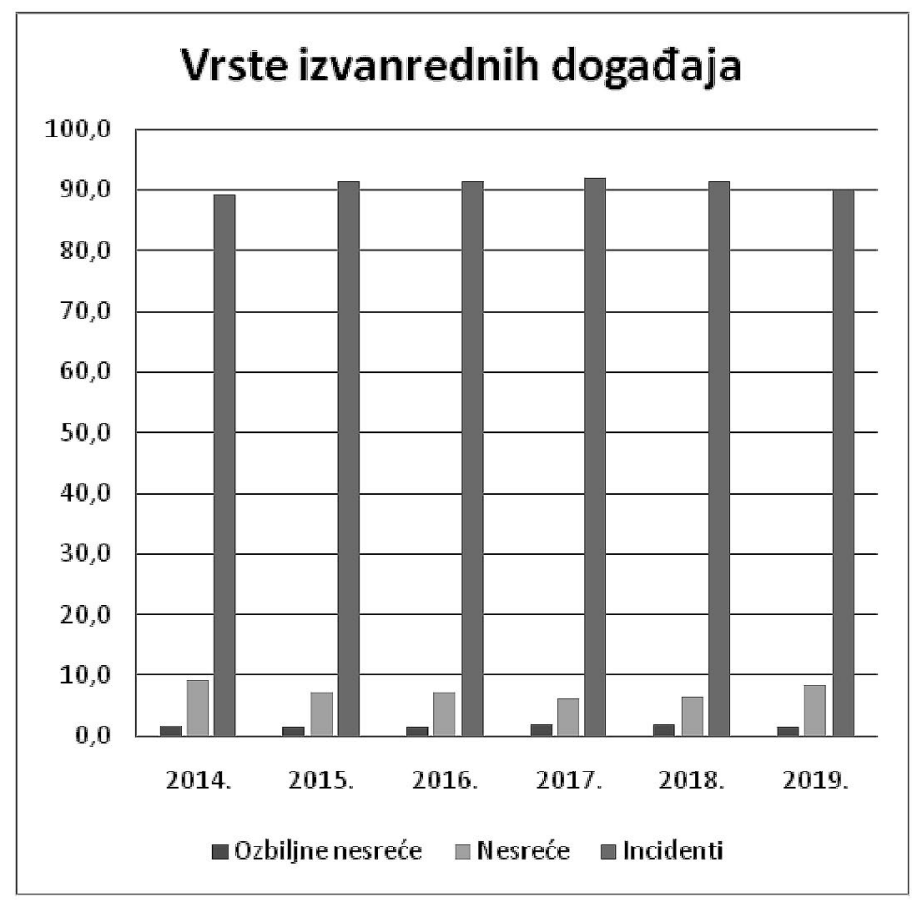

Slika 1. Grafički prikaz udjela izvanrednih dogadaja po vrstama i godinama (\%) Izvor: HŽ Infrastruktura, 2020a (Izradili autori)

Razradom na podvrste ozbiljnih nesreća, kao što je prikazano u Tablici 2, dobiva se precizniji pregled zbog čega dolazi do tako teških izvanrednih događaja.

Tablica 2. Udjel podvrsta ozbiljnih nesreća u željezničkom prometu po godinama (\%)

\begin{tabular}{|l|c|c|c|c|c|c|}
\hline \multicolumn{1}{|c|}{ Ozbiljne nesreće } & 2014. & 2015. & 2016. & 2017. & 2018. & 2019. \\
\hline Sudar vlakova & 0,0 & 0,0 & 0,0 & 0,0 & 0,0 & 0,0 \\
\hline Iskliznuće vlaka & 0,0 & 0,0 & 0,0 & 0,0 & 0,0 & 0,0 \\
\hline Ukupno ŽCP & 25,0 & 46,2 & 15,4 & 30,0 & 38,9 & 46,2 \\
\hline $\begin{array}{l}\text { Nesreće osoba koje su prouzročila željeznička } \\
\text { vozila u pokretu }\end{array}$ & 68,8 & 53,8 & 69,2 & 65,0 & 50,0 & 53,8 \\
\hline Sudar ili iskliznuće pri manevriranju & 0,0 & 0,0 & 0,0 & 0,0 & 0,0 & 0,0 \\
\hline $\begin{array}{l}\text { Sudar ili iskliznuće željezničkog vozila za } \\
\text { posebne namjene }\end{array}$ & 0,0 & 0,0 & 0,0 & 0,0 & 0,0 & 0,0 \\
\hline Požari ili eksplozije na željezničkim vozilima & 0,0 & 0,0 & 0,0 & 0,0 & 0,0 & 0,0 \\
\hline Druge ozbiljne nesreće & 6,3 & 0,0 & 15,4 & 5,0 & 11,1 & 0,0 \\
\hline Ukupno: & 100,0 & 100,0 & 100,0 & 100,0 & 100,0 & 100,0 \\
\hline
\end{tabular}

Izvor: HŽ Infrastruktura, 2020a (Izradili autori) 
Iz Tablice 2 vidi se kako se najveći broj ozbiljnih nesreća događa na ŽCP-ima (od 15,4 do 46,2\%) te pri naletima vlaka na osobe koje hodaju ili prelaze željezničku prugu $(50,0$ do $69,2 \%)$. I u jednom i u drugom slučaju dolazi zbog pogrešaka trećih osoba. Druge ozbiljne nesreće obuhvaćaju strujni udar i slično.

\subsection{Uzroci izvanrednih dogadaja u željezničkom prometu}

Uzroci izvanrednih događaja u željezničkom prometu prate se prema osobnim propustima zaposlenika upravitelja infrastrukture, tehničkim nedostacima na infrastrukturnim podsustavima ili željezničkim vozilima HŽ Infrastrukture d.o.o., osobnim propustima zaposlenika željezničkog prijevoznika, tehničkim nedostacima na željezničkim vozilima željezničkog prijevoznika, nesmotrenom ili zlonamjernom djelovanju drugih osoba te radi vremenskih nepogoda (HŽ Infrastruktura, 2013). Prema Analizi izvanrednih dogadaja za 2019. najčešći su uzroci od ukupnog broja svih izvanrednih događaja nesmotreno ili zlonamjerno djelovanje drugih osoba (od 67,2 do 71,8\%) i tehnički nedostaci na infrastrukturnim podsustavima ili željezničkim vozilima HŽ Infrastrukture d.o.o. (od 10,3 do 16,1\%). Kad su u pitanju osobe kao uzroci izvanrednih događaja, postotci su prikazani u Tablici 3 .

Tablica 3. Pogreške osoba kao uzroci izvanrednih dogadaja u željezničkom prometu (\%)

\begin{tabular}{|l|c|c|c|c|c|c|}
\hline \multicolumn{1}{|c|}{ Uzroci } & $\mathbf{2 0 1 4 .}$ & $\mathbf{2 0 1 5 .}$ & $\mathbf{2 0 1 6 .}$ & $\mathbf{2 0 1 7 .}$ & $\mathbf{2 0 1 8 .}$ & $\mathbf{2 0 1 9 .}$ \\
\hline Korisnici ŽCP-a & 69,0 & 74,1 & 71,0 & 75,8 & 78,0 & 79,2 \\
\hline Neovlaštene osobe & 25,6 & 19,8 & 21,2 & 18,4 & 16,1 & 13,5 \\
\hline Treće osobe & 4,5 & 5,8 & 7,5 & 5,7 & 5,9 & 7,1 \\
\hline Putnici & 0,8 & 0,3 & 0,3 & 0,1 & 0,0 & 0,2 \\
\hline Ukupno: & 100,0 & 100,0 & 100,0 & 100,0 & 100,0 & 100,0 \\
\hline
\end{tabular}

Izvor: HŽ Infrastruktura, 2020a (Izradili autori)

Kao što se vidi najveći je broj propusta kod korisnika ŽCP-a (od 69,0 do 79,2\%) i neovlaštenih osoba (od 13,5 do 25,6\%). Trend je porasta propusta korisnika ŽCP-a. Odnos između propusta željezničkih radnika i trećih osoba kreće se od 1,7 do 4,5\%.

\subsection{Posljedice izvanrednih dogadaja u željezničkom prometu}

Prema Pravilniku o postupanju u slučaju izvanrednog dogadaja (HŽ Infrastruktura, 2013) posljedice se dijele na smrtno stradale i teže ozlijeđene osobe te na prekid prometa i materijalnu štetu. U Tablici 4 prikazan je pregled posljedica izvanrednih događaja za zadnjih šest godina. 
Tablica 4. Posljedice izvanrednih dogadaja u željezničkom prometu (\%)

\begin{tabular}{|l|l|c|c|c|c|c|c|}
\hline \multicolumn{2}{|c|}{ Posljedice } & 2014. & 2015. & 2016. & 2017. & 2018. & 2019. \\
\hline \multirow{2}{*}{ Smrtno stradali } & na ŽCP-u & 7 & 8 & 2 & 7 & 8 & 6 \\
\cline { 2 - 8 } & ostali & 12 & 7 & 11 & 14 & 12 & 7 \\
\hline \multirow{2}{*}{ Ukupno smrtno stradali } & 19 & 15 & 13 & 21 & 20 & 13 \\
\hline \multirow{2}{*}{ Teže ozlijeđeni } & na ŽCP-u & 5 & 11 & 5 & 5 & 5 & 6 \\
\cline { 2 - 8 } & ostali & 13 & 10 & 13 & 11 & 2 & 7 \\
\hline \multicolumn{2}{|l}{ Ukupno teže ozlijeđeni } & 18 & 21 & 18 & 16 & 7 & 13 \\
\hline
\end{tabular}

Izvor: HŽ Infrastruktura, 2020a (Izradili autori)

Iz Tablice 4 vidljivo je kako godišnje na prugama u RH prosječno smrtno stradava od 13 do 21 osoba, a prosječno teže ozlijeđeno bude od 7 do 21 osoba kao što se vidi na Slici 2.

\section{Usmrćeno i teže ozlijeđeni}

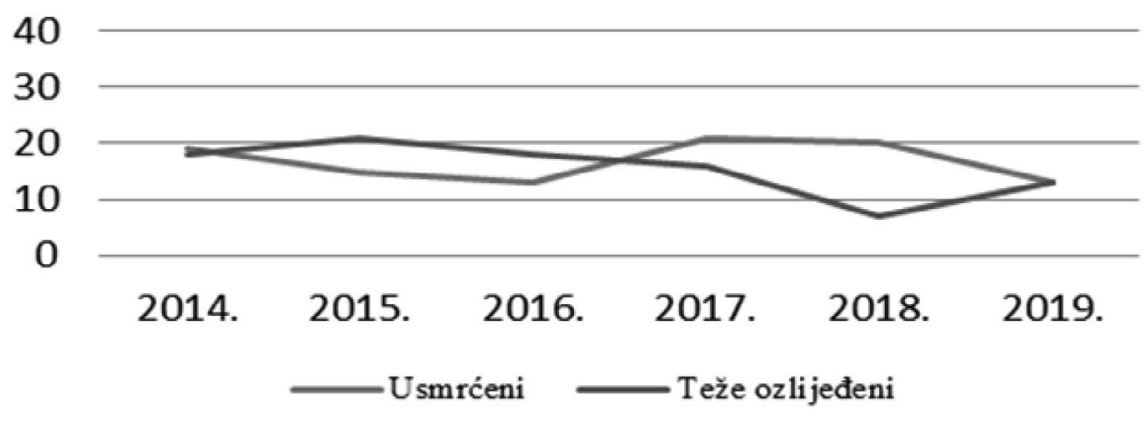

Slika 2. Grafički prikaz smrtno stradalih i teže ozlijedenih osoba godinama (\%) Izvor podataka: HŽ Infrastruktura, 2020a (Izradili autori)

Iako je to puno manji broj od smrtno stradalih u cestovnom prometu cilj je postići $0 \%$ smrtno stradalih i ozlijeđenih u željezničkom prometu. Ono što je posebno važno naglasiti jest to da su na ŽCP-ima upravo sudionici cestovnog prometa najugroženiji sudionici. Ove analize stoga su podloga za pripremanje preventivnih akcija prema trećim osobama.

\section{PREVENTIVNE AKCIJE ŽELJEZNIČKIH PODUZEĆA}

HŽ Infrastruktura d.o.o. članica je Hrvatskog poslovnog savjeta za održivi razvoj, a od 2017. godine izrađuje Izvješće o održivosti koje je usklađeno s odredbama Direktive o nefinancijskom izvještavanju i raznolikosti (2014/95/EU) i Zakona o izmjenama i dopu- 
nama Zakona o računovodstvu (NN 120/2016). Koliko je važna povezanost željezničkih poduzeća sa svojom zajednicom i dionicima govore dvije činjenice:

- razvoj željezničkog prometa u prošlosti bio je pokretač razvoja društva, naselja i gospodarstva; i

- širenjem naselja uz prugu danas se sve više događa da je željeznička infrastruktura postala prepreka i smetnja za kvalitetno kretanje i komunikaciju ljudi.

\subsection{Akcija „Vlak je uvijek brži“ na ŽCP-ima}

U četvrtom poglavlju Izvješća o održivosti u kojem se obrađuje suradnja sa zajednicom i dionicima nalazi se edukativno preventivna akcija „Vlak je uvijek brži“. U sklopu svoje uloge kao društveno odgovoran poslovni subjekt koji skrbi o kvaliteti života svoje zajednice, $H Z ̌$ je 2000. godine pokrenuo edukativno-preventivnu akciju „Vlak je uvijek brži“, koja se provodi i danas. Akcija je namijenjena svim sudionicima u prometu, a osobito vozačima cestovnih vozila i mladima, kako bi se ukazalo na tipične greške pri prelaženju preko pruge te na česte slučajeve nepoštivanja pravila. U sklopu akcije ističe se osvješćivanje sudionika u prometu o vlastitoj odgovornosti jer je pozorno i oprezno sudjelovanje u prometu glavni preduvjet sigurnosti. Tijekom 2019. godine akcije „Vlak je uvijek brži“ kao akcije upozorenja održane su na željezničko-cestovnim prijelazima u Starim Jankovcima, Požegi i Kanfanaru (HŽ Infrastruktura, 2020c). Na Slici 3 prikazana je provedba akcije „Vlak je uvijek brži“ i razgovor s profesionalnim vozačem.

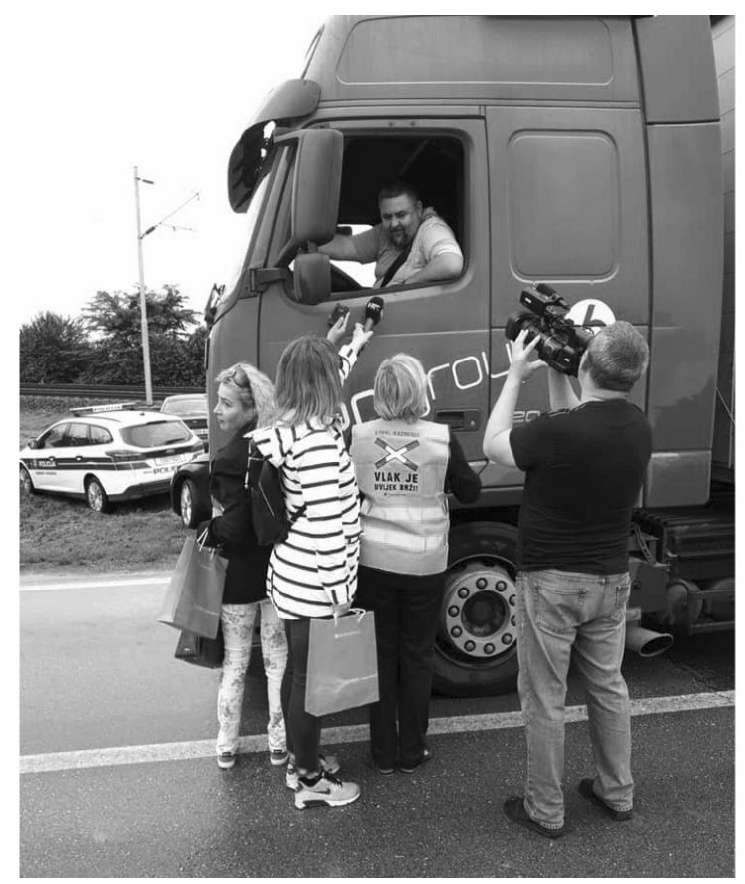

Slika 3. Akcija ,Vlak je uvijek brži““ na ŽCP-u (Izvor: autori) 
Edukativno-preventivne aktivnosti akcije „Vlak je uvijek brži“ održavaju se u osnovnim i srednjim školama jer se posebna pozornost posvećuje sigurnosti mladih. Akcija „Vlak je uvijek brži“ održava se u osnovnim školama, najčešće onima koje se nalaze u blizini željezničke pruge. Posljednjih nekoliko godina, pa tako i u 2019. godini, vidljivo je da su škole prepoznale i prihvatile akciju „Vlak je uvijek brži“ te su vrlo česti pozivi škola za održavanje radionica $s$ njihovim učenicima. Putem radionica djeca se upoznaju $s$ rizicima i pravilima ponašanja u željezničkom prometu, ali se upozorava djecu i na nepoželjna i opasna ponašanja kao što su igranje po pruzi i uz prugu, penjanje na vagone te gađanje vlakova kamenjem. Edukativno-preventivnim radionicama „Vlak je uvijek brži“ tijekom 2019. godine obuhvaćene su škole iz Sesvetskog Kraljevca, Zagreba, Odre, Karlovca i Kanfanara. Radionicama je obuhvaćeno 1.067 učenika iz devet škola (HŽ Infrastruktura, 2020c). Na Slici 4 prikazana je zainteresiranost učenika tijekom provedbe akcije „Vlak je uvijek brži“.

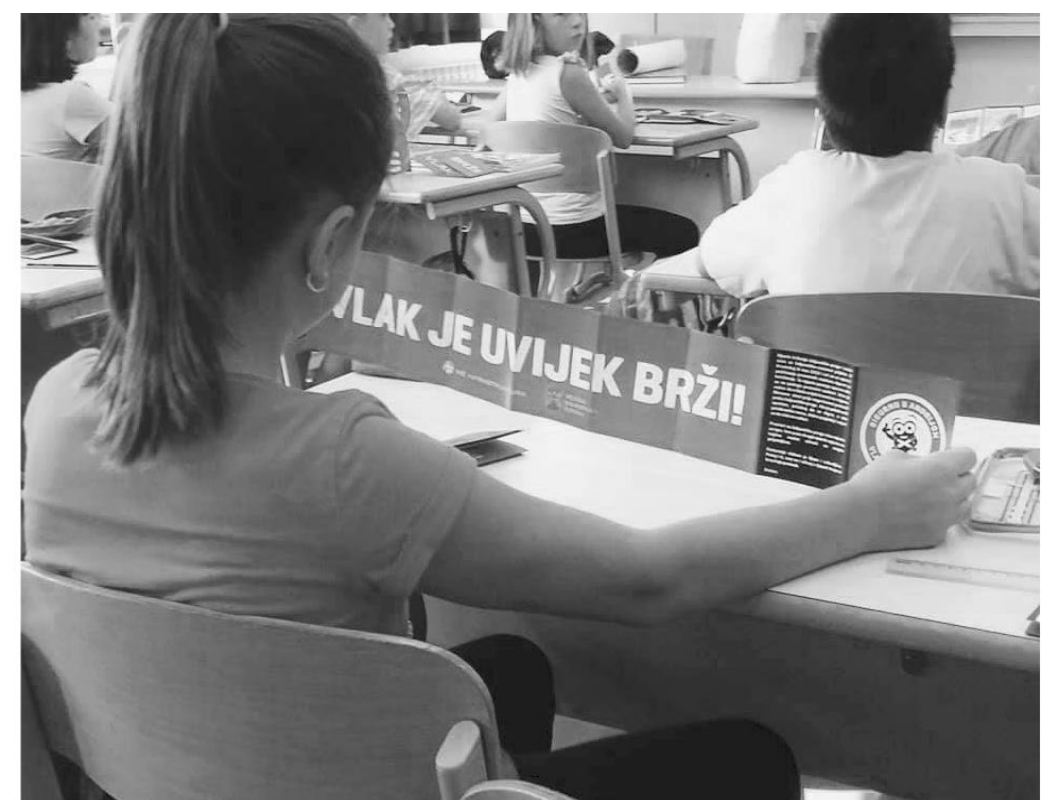

Slika 4. Edukativno preventivna akcija ,Vlak je uvijek brži“ u osnovnoj školi (Izvor: autori)

U 2019. godini ostvarena je i zanimljiva suradnja s Osnovnom školom „Ivana Brlić Mažuranić“ iz Strizivojne. U Izvješću o održivosti stoji kako u školi djeluje Eko škola „Ivana Brlić Mažuranić" koja se obratila HŽ Infrastrukturi sa zanimljivim projektom. Naime, jedna je od njihovih aktivnosti i održavanje akcije Eko čistka u sklopu koje uređuju ili čiste odabrani dio u svome kraju. Učenici su uredili prostor oko željezničkog kolodvora. Očistili su i uredili cvjetne gredice te popravili i obojili klupe. Cvijeće koje su koristili za uređenje učenici su sami uzgojili (HŽ Infrastruktura, 2020c). Ovakve uspješne akcije smjer su u kojem treba ići i daljnja suradnja željezničkih poduzeća sa svojom zajednicom i dionicima. 


\subsection{Konferencija ILCAD u Zagrebu}

Važnost ulaganja u sigurnost prometa na ŽCP-ima prepoznata je u cijelom svijetu pa se od 2009. godine označava svjetski Dan svjesnosti i opasnostima na željezničko cestovnim prijelazima (ILCAD). Tog dana održava se konferencija u jednoj od zemalja članica te se u svakoj zemlji članici provodi preventivna akcija na ŽCP-ima.

„Od 2011. akcija 'Vlak je uvijek brži' dio je međunarodne kampanje ILCAD, obilježavanja Međunarodnog dana svjesnosti o opasnostima na željezničko-cestovnim prijelazima. U 2019. godini u Starim Jankovcima povodom ILCAD-a održana je akcija upozorenja na željezničko - cestovnom prijelazu koji je vrlo prometan, a u velikom broju se radi o teretnim vozilima i profesionalnim vozačima" (HŽ Infrastruktura, 2020c).

HŽ Infrastruktura d.o.o. bila je, u suradnji s Fakultetom prometnih znanosti, domaćin 10. konferencije ILCAD 2018. godine. Na Konferenciji se okupilo oko 180 međunarodnih i domaćih stručnjaka iz 29 zemalja svijeta koji se bave sigurnošću na željezničko-cestovnim prijelazima. Na početku konferencije prikazan je petominutni video sažetak preventivno-edukativnih mjera koje Fakultet prometnih znanosti i HŽ Infrastruktura d.o.o. dvije godine kontinuirano provode u sklopu projekta „Implementacija mjera za povećanje sigurnosti najranjivijih sudionika u prometu na željezničko-cestovnim prijelazima" koji je dio Nacionalnog programa sigurnosti cestovnog prometa Republike Hrvatske 2011.-2020. godine. U sklopu cjelodnevnih događanja, na prostoru ispred Muzeja Mimara u Zagrebu od 12.00 do 19.00 sati na rasporedu je bio program namijenjen mladima:

- edukativno - preventivne radionice povezane sa sigurnosti na željezničko - cestovnim prijelazima, nagradne igre, kvizovi znanja za učenike osnovnih škola, umjetnički kutak sa studentima Akademije likovnih umjetnosti i školarcima;

- Hrvatski autoklub (HAK) izložio je simulator prevrtanja koji je bio posebno interesantan mladim vozačima;

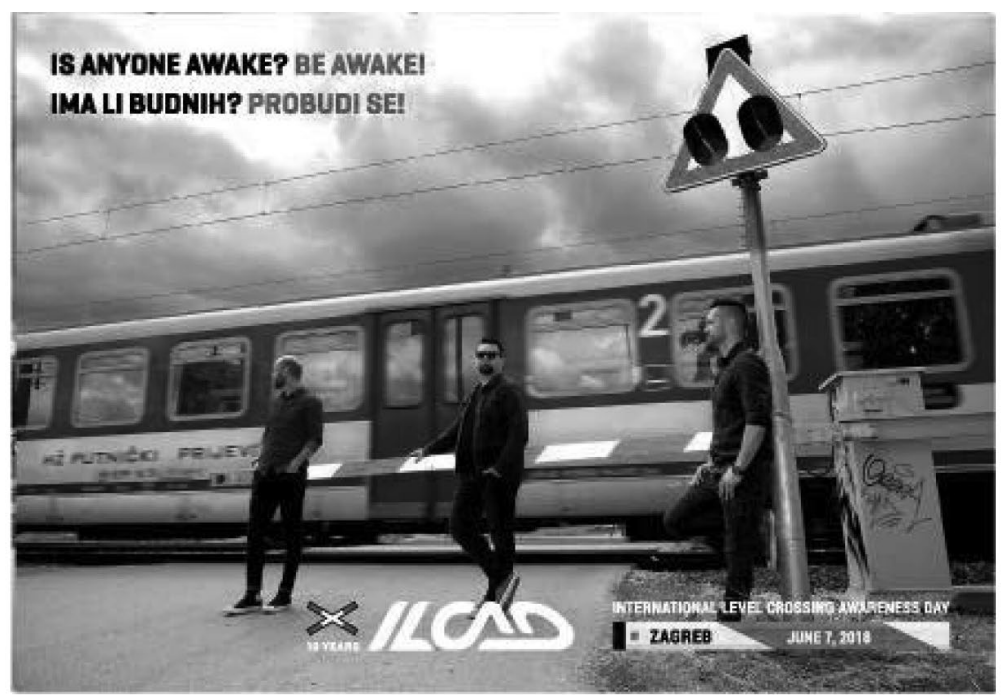

Slika 5. Glazbeni sastav Vatra na ILCAD konferenciji 2018. u Zagrebu (Izvor: autori) 
- Ministarstvo unutarnjih poslova sa svojim programom za mlade bicikliste; i

- studenti Fakulteta prometnih znanosti prezentirali su aplikaciju sigurne i rizične vožnje preko željezničko - cestovnog prijelaza koju su sudionici mogli testirati (HŽ Infrastruktura, 2020b).

Sadržajan program ispred muzeja Mimara zaokružen je nastupom glazbenog sastava „Vatra“ čija je pjesma „Ima li budnih“, kao što se vidi na Slici 5, bila slogan ILCAD konferencije u Zagrebu.

\section{UMJETNIČKE INTERVENCIJE U ČVORU RIJEKA KAO PREVENTIVNE AKCIJE}

Pozitivna iskustva s edukativno-preventivnih akcija „Vlak je uvijek brži“ te organizacije „10. konferencije ILCAD“ u Zagrebu 2018. godine bili su poticaj za nove inovativne ideje i akcije. Jedna takva ideja javila se za grad Rijeku:

- Rijeka je grad koji u 2020. godini nosi titulu „Europske prijestolnice kulture“ s programom „Luka različitosti“ i ciljem stvaranja grada kulture i kreativnosti za Europu i budućnost;

- Rijeka je grad koji u svom imenu nosi simbol vode kao simbol života i protočnosti; i

- Rijeka je centar povijesne, kulturne, ali i prometne različitosti i povezanosti.

Osim pomorske luke, u Rijeci se nalaze najvažnije cestovne i željezničke prometnice prema srednjoj i sjeveroistočnoj Europi, a željeznički je promet prioritet europske prometne politike.

\subsection{Uključivanje željezničkih poduzeća u program „Luka različitosti“}

Rijeka je prometna poveznica mora i kopna. Željeznička poduzeća kao važan dio prometne različitosti i povezanosti trebala su prepoznati tu priliku te se aktivno uključiti svojim edukativno - preventivnim akcijama. Na te akcije se u čvoru Rijeka moglo gledati kroz tri različita pristupa:

- reaktivni pristup - željeznička poduzeća udovoljavaju standardima zbog zakona i teže zadržavanju postojećeg stanja bez dodatnih aktivnosti;

- proaktivni pristup - željeznička poduzeća uvode vlastite programe i druge modele (preventivne akcije „Vlak je uvijek brži“ i „Stvaraj, a ne uništavaj“); $i$

- pristup „stvaranja dobiti“ - traženje novih rješenja koja će stvarati dodanu vrijednost željezničkim poduzećima i gradu (društveno odgovorno poslovanje i održivi razvoj). U ovom slučaju se dodana vrijednost traži kroz urbane umjetničke intervencije na postojećim željezničkim objektima.

Reaktivni pristup znači nezainteresiranost željezničkih poduzeća za izravno sudjelovanje u gradu Rijeci kao „Europskoj prijestolnici kulture“. Proaktivni pristup obuhvaća ponudu gotovih programa preventivnih akcija u gradu Rijeci tijekom 2020. godine. Pristup „stvaranja dobiti“ podrazumijeva prepoznavanje željeznice u gradu Rijeci kao nezaobilaznog dijela prometnog, gospodarskog, graditeljskog, turističkog i kulturnog podsustava. 
Tijekom 2019. godine obuhvaćen je cjelokupni čvor Rijeka te su utvrđeni željeznički objekti na kojima bi se mogle raditi određene umjetničke intervencije:

- mostovi sa zakovicama kao glavni simbol povijesne, kulturne i prometne povezanosti;

- pruga L212 Rijeka - Rijeka Brajdica;

- željezničko cestovni i pješački prijelazi;

- ograda uz područje kolodvora Rijeka; i

- galerija i ostali sadržaji.

\section{2. Željezničko-cestovni i pješački prijelazi u čvoru Rijeka}

Prema Pravilniku o načinu osiguravanja prometa na željezničko-cestovnim prijelazima $i$ pješačkim prijelazima preko pruge (NN 111/15) ŽCP jest mjesto križanja željezničke pruge ili industrijskoga kolosijeka i ceste u istoj razini, a može uključivati i križanje pruge $s$ pješačkom i biciklističkom stazom ili drugim putovima namijenjenima prelaženju ljudi, životinja, vozila ili strojeva. Jedan od najčešćih prigovora sudionika cestovnog prometa na ŽCP odnosi se na dugo čekanje na dolazak vlaka. Pod dugim čekanjem obično se podrazumijevaju 3 minute i više. Osobito kad se u obzir uzme kako postoji niz ŽCP-a gdje vlak dolazi za manje od jedne minute. Većini korisnika ŽCP-a nije jasno zašto se taj kraći period čekanja ne primjeni na svim ŽCP-ima.

Mnogi pješaci, pa i vozači cestovnih vozila, ne čekaju dolazak vlaka, već idu preko pruge pored upaljene signalizacije. Ako se već ne može skratiti vrijeme dolaska vlaka do ŽCP-a ili pješačkog prijelaza preko pruge, može li se ikako privući pozornost ljudi kako ne bi prelazili prugu dok je signalizacija upaljena i na taj način riskiraju svoj život? Što bi to ljudima moglo biti toliko zanimljivo i privlačno kako bi usporili svoj užurbani ritam? Može li se prijelaz prilagoditi čovjeku, učiniti ga zanimljivijim te ga približiti korisniku, zainteresirati ga da pričeka i poštuje prometnu signalizaciju / prolaz vlaka? Motiviranje sudionika cestovnog prometa da budu strpljivi na ŽCP-ima bila je nit vodilja za traženje rješenja na tri ŽCP / ŽPP u Čvoru Rijeka:

- ŽCP Krešimirova ulica (na ulazu u kolodvor Rijeka),

- ŽPP Krnjevo i

- ŽPP Sušak-Pećine.

ŽCP Krešimirova ulica (Slika 6), kod samog kolodvora Rijeka, ima niz posebnosti zbog kojih mu je potrebno posvetiti posebnu pozornost:

- $\quad s$ jedne je strane ulaz u kolodvor, a s druge tunel pa je slaba vidljivost vlaka;

- to je željezničko - cestovni i željezničko - pješački prijelaz;

- to je ŽCP na kojem se vlak čeka dulje od 3 minute zbog ograničenja tehnološkog rješenja pruge;

- u zadnjih 5 godina na tom prijelazu bilo je 50 lomova polubranika što govori o potrebi podizanja svijesti vozača cestovnih vozila;

- šteta na uređajima bila je 107.000 kuna;

- za vrijeme rada signalizacije na ŽCP preko $98 \%$ nestrpljivih građana i turista prelazi prugu, za sada bez posljedica, ali negiraju prometna pravila i propise i na to treba djelovati; i 
- prilikom približavanja vlaka pojačava se zvučna signalizacija.

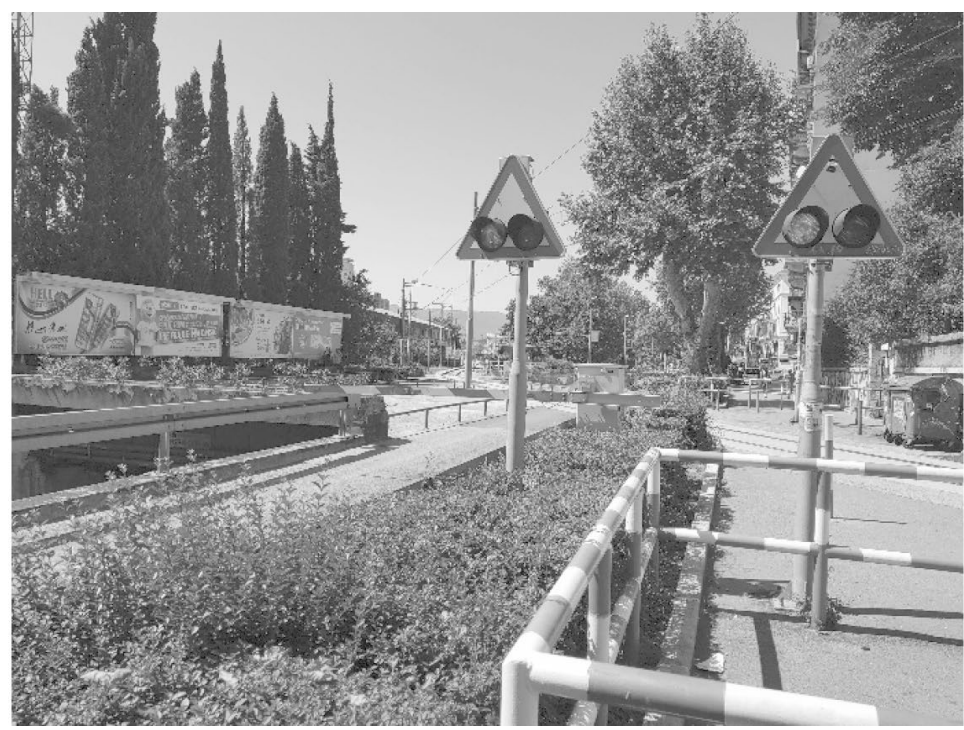

Slika 6. ŽCP / ŽPP Krešimirova ulica (Izvor: autori)

Na pješačkom prijelazu i stajalištu Krnjevo (Slika 7), vrijeme kao da je stalo. Obnovljeno stajalište zadovoljava formu i ništa više. $S$ aspekta sigurnosti prometa, to je i dovoljno jer statistike izvanrednih događaja pokazuju kako u zadnjih pet godina nije bilo stradavanja. Ipak, tu se kriju i još neke lijepe i manje lijepe činjenice:

- pogled na more sa stajališta Krnjevo prelijep je da bi ostao nezabilježen; i

- na toj dionici pruge bilo je suicida, krađe i uništavanja željezničke imovine.

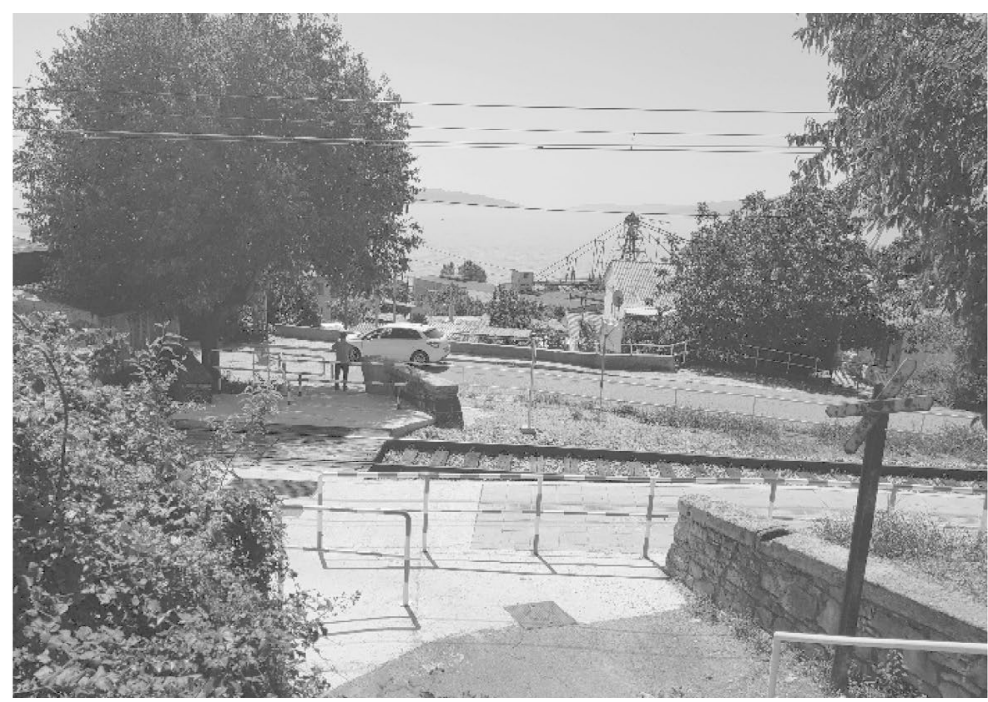

Slika 7. ŽCP / Krnjevo (Izvor: autori) 
ŽPP Sušak Pećine (Slika 8) još je jedan od prijelaza koji udovoljavaju propisima i standardima te statistike izvanrednih događaja pokazuju kako nije bilo težih izvanrednih događaja. Ipak, kao i ŽCP Krešimirova ulica, ima neke svoje posebnosti:

- $\quad s$ jedne je strane veliki trgovački centar, a s druge naselje i učenički dom;

- nakon prijelaza preko ŽPP-a, građani se susreću i s cestovnim pješačkim prijelazom, koji se nalazi na zavoju, neposredno uz trgovački centar;

- na vlak se čeka dulje od 3 minute zbog ograničenja tehnološkog rješenja pruge; i

- za vrijeme rada signalizacije na ŽPP, preko 98\% nestrpljivih građana prelazi prugu.

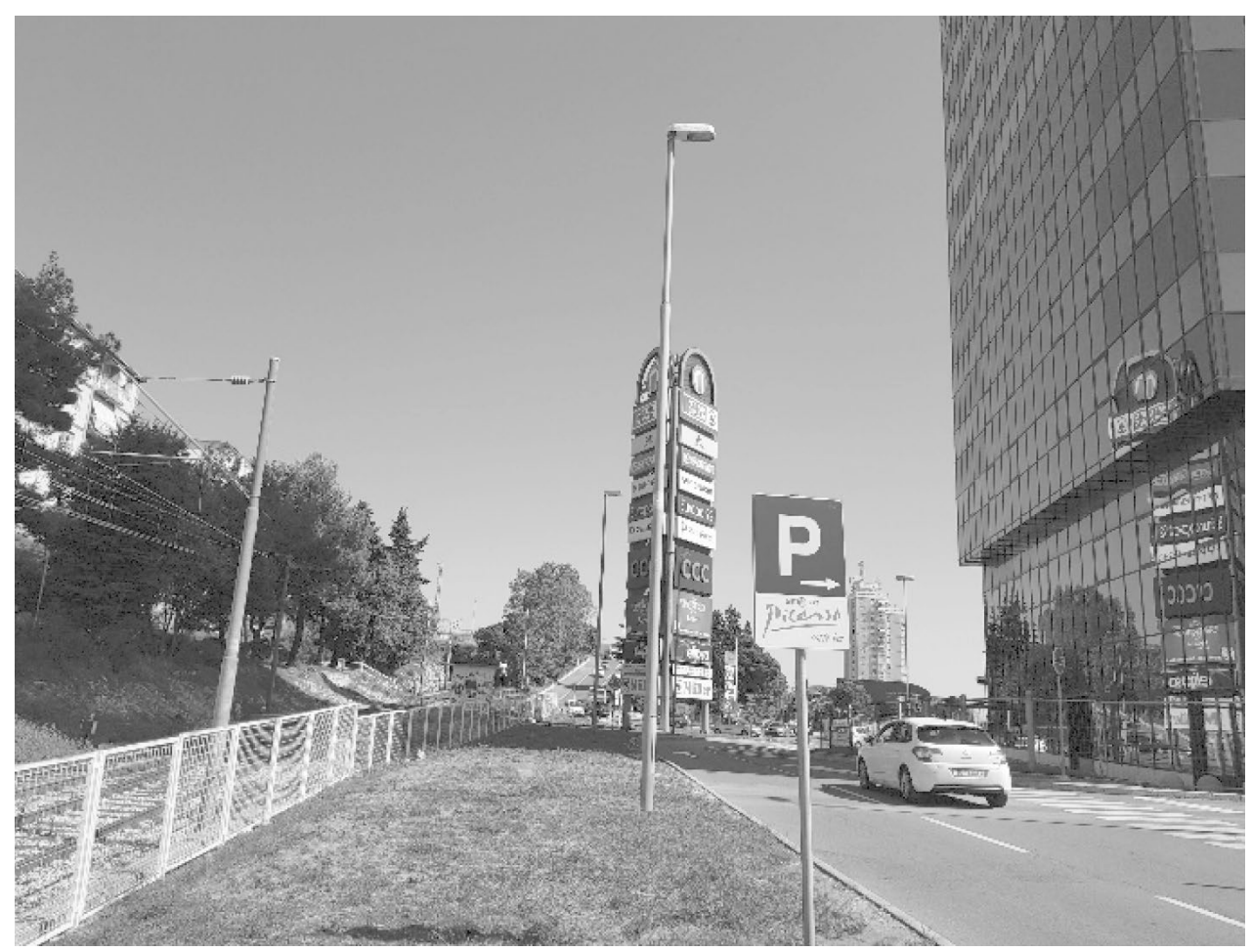

Slika 8. ŽPP Sušak-Pećine (Izvor: autori)

\subsection{Umjetničke intervencije i preventivne akcije na željezničko-cestovnim i pješačkim prijelazima u čvoru Rijeka}

Nepravilno ponašanje sudionika cestovnog prometa na ŽCP-ima najčešce je posljedica nedovoljnog znanja i nedovoljne svjesnosti o opasnostima u željezničkom prometu te nestrpljivosti ili uključenosti ,auto pilota“ vozača i pješaka u cestovnom prometu. Zbog toga su predložene intervencije usmjerene prema zadržavanju, educiranju, promjeni rutine i podizanje prometne kulture sudionika cestovnog prometa. Prijedlozi umjetničkih intervencija na tri ŽCP-a i ŽPP-a u čvoru Rijeka predstavljaju rezultate provedenog istraživanja i nalaze se u Tablici 5. 
Tablica 5. Prijedlog umjetničkih intervencija na ŽCP-ima i ŽPP-ima u čvoru Rijeka (Izradili autori)

\begin{tabular}{|c|c|}
\hline Prijedlozi umjetničkih intervencija & Opis \\
\hline $\begin{array}{l}\text { Informativna ploča s QR kodom - info, } \\
\text { edukacija, prevencija }\end{array}$ & $\begin{array}{l}\text { Zadržavanje i educirane pješaka na ŽPP-u } \\
\text { kako bi imali strpljenja čekati prolazak vlaka }\end{array}$ \\
\hline $\begin{array}{l}\text { QR kod povezati s kreditnom karticom i } \\
\text { stvarati dobre navike kod korisnika }\end{array}$ & $\begin{array}{l}\text { Podizanje prometne kulture nagrađivanjem } \\
\text { dobrih navika u prometu }\end{array}$ \\
\hline $\begin{array}{l}\text { „Školica“ na nogostupu prije mimoilazne } \\
\text { ograde }\end{array}$ & $\begin{array}{l}\text { Zadržavanje pješaka na ŽPP-u kako bi imali } \\
\text { strpljenja čekati prolazak vlaka }\end{array}$ \\
\hline Pametna klupa - solarna; punjač mobitela & $\begin{array}{l}\text { Zadržavanje pješaka i stvaranje dodane } \\
\text { vrijednosti dok se na ŽPP-u čeka prolazak } \\
\text { vlaka }\end{array}$ \\
\hline $\begin{array}{l}\text { Uočljivom bojom obilježiti prijelaz preko } \\
\text { ŽCP-a / ŽPP-a }\end{array}$ & $\begin{array}{l}\text { Promjene rutine u prometu kako bi se } \\
\text { vozačima i pješacima vratila pozornost na } \\
\text { promet }\end{array}$ \\
\hline $\begin{array}{l}\text { Edukativne poruke na nogostupu, na } \\
\text { stajalištu uz žutu liniju, na zidiću i tendi na } \\
\text { žičanoj ogradi }\end{array}$ & $\begin{array}{l}\text { Zadržavanje i educiranje pješaka na ŽPP-u } \\
\text { kako bi imali strpljenja čekati prolazak vlaka }\end{array}$ \\
\hline $3 \mathrm{D}$ grafit na cesti uzduž pruge & $\begin{array}{l}\text { Promjene rutine u prometu kako bi se } \\
\text { vozačima i pješacima vratila pozornost na } \\
\text { promet }\end{array}$ \\
\hline Obojati tunel upozoravajućim bojama & $\begin{array}{l}\text { Promjene rutine u prometu kako bi se } \\
\text { vozačima i pješacima vratila pozornost na } \\
\text { promet }\end{array}$ \\
\hline $\begin{array}{l}\text { Obojati stepenice edukativnim prometnim i } \\
\text { proaktivnim porukama }\end{array}$ & $\begin{array}{l}\text { Promjene rutine u prometu kako bi se } \\
\text { vozačima i pješacima vratila pozornost na } \\
\text { promet }\end{array}$ \\
\hline $\begin{array}{l}\text { Obojati stajalište, stvoriti „sjenila“; zaštitu od } \\
\text { sunca te obojati zid kuće }\end{array}$ & $\begin{array}{l}\text { Zadržavanje pješaka i stvaranje dodane } \\
\text { vrijednosti dok se na ŽPP-u čeka prolazak } \\
\text { vlaka }\end{array}$ \\
\hline $\begin{array}{l}\text { Obilježiti mjesto „za zagrljaje i poljupce“; } \\
\text { „Zastani, pričekaj da vlak prođe!“ }\end{array}$ & $\begin{array}{l}\text { Promjene rutine u prometu kako bi se } \\
\text { pješacima vratila pozornost na promet }\end{array}$ \\
\hline $\begin{array}{l}\text { Postaviti vidikovac s dalekozorom prema } \\
\text { moru i otocima }\end{array}$ & $\begin{array}{l}\text { Promjene rutine u prometu kako bi se } \\
\text { pješacima vratila pozornost na promet }\end{array}$ \\
\hline $\begin{array}{l}\text { Postaviti videokameru koja snima ponašanje } \\
\text { na ŽCP-u, stajalištu, ali i igrače školice }\end{array}$ & $\begin{array}{l}\text { Podizanje prometne kulture nagrađivanjem } \\
\text { dobrih navika u prometu }\end{array}$ \\
\hline $\begin{array}{l}\text { Ugraditi pametni „semafor“ s odbrojavanjem } \\
\text { do dolaska vlaka }\end{array}$ & $\begin{array}{l}\text { Promjene rutine u prometu kako bi se } \\
\text { pješacima vratila pozornost na promet }\end{array}$ \\
\hline
\end{tabular}

Navedene inovativne ideje i rješenja bilo bi potrebno provoditi u sklopu edukativno-preventivnih akcija na samim ŽCP-ima i u školama. 


\section{ZAKLJUČAK}

U željezničkom prometu, tehnička rješenja signalno sigurnosnih uređaja dovedena su do visoke razine pouzdanosti, a željeznički se radnici trajno poučavaju i educiraju. Međutim, statistički se pokazatelji neće popraviti sami od sebe. Zbog toga je potrebno djelovati i prema sudionicima u prometu koji o opasnostima u željezničkom prometu najmanje znaju. Unaprjeđenje sigurnosti prometa posebice na željezničko-cestovnim prijelazima te smanjenje broja smrtno stradalih i ozlijeđenih sudionika u prometu ne smiju biti dio trenda ili samopromocije prijevozničkih organizacija. Učinkovito unaprjeđenje sigurnosti na ŽCP-ima traži stalne preventivne aktivnosti u cilju podizanja svjesnosti sudionika u prometu. To najbolje pokazuju dosadašnje edukativno preventivne akcije na ŽCP-ima i one su poticaj za traženje novih rješenja i ideja.

Stoga je prijedlog inovativnih umjetničkih intervencija na ŽCP-ima grada Rijeke pozitivan primjer koji se temelji na suvremenim smjernicama društveno odgovornog poslovanja željezničkih poduzeća i održivog razvoja grada. Međutim, uložena sredstva željezničkih poduzeća ne trebaju imati samo svrhu promocije željeznice za vrijeme trajanja projekta „Rijeka - Europska prijestolnica kulture“, nego trebaju omogućiti dugoročno poboljšanje poslovanja, racionalizaciju troškova te stvaranje nove vrijednosti za željeznička poduzeća.

Problemi nastali zbog pandemije koronavirusa u velikoj su mjeri onemogućili kako uspješnu realizaciju projekta „Luka različitosti“ i Rijeke kao „Europske prijestolnice kulture“ tako i primjenu inovativnih rješenja na ŽCP / ŽPP u čvoru Rijeka. Prezentacija postojećeg stanja i prijedloga rješenja na ŽCP / ŽPP u radu trag su teške 2020. godine za neka bolja buduća vremena i njihovu realizaciju.

\section{LITERATURA}

HŽ Infrastruktura (2013). Pravilnik o postupanju u slučaju izvanrednog događaja. Pravilnik HŽI-631.

HŽ Infrastruktura (2020a). Analiza izvanrednih dogadaja za 2019. Zagreb: HŽ Infrastruktura.

HŽ Infrastruktura (2020b). 10. Međunarodna konferencija ILCAD u Zagrebu. URL: https://www.hzinfra.hr/edukativno-preventivni-program-za-mlade-kod-muzejamimara/ (15.12.2020.)

HŽ Infrastruktura (2020c). Izvješće o održivosti za 2019. Zagreb: HŽ Infrastruktura.

Pravilnik o načinu osiguravanja prometa na željezničko-cestovnim prijelazima i pješačkim prijelazima preko pruge. Narodne novine, 111/15.

Zakon o sigurnosti i interoperabilnosti željezničkog sustava. Narodne novine, 63/20. 


\title{
THE ROLE OF THE RAILWAY TRAFFIC IN THE CITY OF RIJEKA AS A CENTRE OF HISTORICAL, CULTURAL AND TRAFFIC DIVERSITY AND CONNECTIONS
}

\author{
Sanja Paić and Dražen Kaužljar
}

\begin{abstract}
From the aspect of railway safety, the technical level of safety and training of railway workers is at a high level. Analyses of extraordinary events in railway traffic reveal that the largest number of serious accidents are caused by other people. These are people who are not directly involved in rail transport, such as railway workers or passengers. For decades, railway companies in Croatia have been carrying out preventive actions to inform the public, such as the "Train is always faster" campaign. Occasionally, the preventive actions are linked to events outside of the railway system. One of them is the promotion of Rijeka as the European Capital of Culture in 2020. The city of Rijeka is a centre of historical, cultural, but also traffic diversity and connections. Transport connections refer to the Port of Rijeka and the Mediterranean Corridor. This one-year event was an excellent opportunity to raise the level of safety and culture in railway transport. The main thesis of this paper was that urban, artistic intervention on railway facilities in Rijeka can be based on modern guidelines of socially responsible business and sustainable development. First of all, it was necessary to make an analysis of the condition of railway facilities on which it was possible to carry out urban artistic intervention. These are railway bridges, railway roads and pedestrian crossings, railway fences, and railway and other buildings. To do so we used the method of observing and photographing the existing situation. The analysis resulted in the identification and suggestions for the implementation of preventive actions in the railway area in Rijeka for the reduction of the number of extraordinary events.
\end{abstract}

Keywords: European Capital of Culture, urban intervention, transport accessibility, city of Rijeka, traffic culture, railroad crossings

\section{DIE ROLLE DES EISENBAHNVERKEHRS IN RIJEKA - EINEM ZENTRUM DER HISTORISCHEN, KULTURELLEN UND VERKEHRSVIELFALT UND -VERBINDUNGEN}

\author{
Sanja Paić und Dražen Kaužljar
}

\section{Zusammenfassung}

Aus dem Aspekt der Sicherheit des Bahnverkehrs ist die technische Sicherheit und Kompetenz von Bahnarbeitern aufeiner hohen Ebene. Analysen von außerordentlichen Vorfällen im Bahnverkehr zeigen, dass der Großteil von schweren Unfällen von dritten Personen verursacht wird. Das sind Personen, die nicht unmittelbar in Verbindung mit Bahnverkehr stehen, wie Reisende und Eisenbahner. Jahrzehntelang werden in Kroatien verschiedene Präventionsaktivitäten durchgeführt, wie zum Beispiel „Der Zug ist immer schneller". Ab und zu finden Präventionsaktivitäten der Eisenbahnbetriebe in Verbindung mit externen Vorfällen statt. Eine davon ist die Werbung für Rijeka, die Europäische Kulturhauptstadt im Jahr 2020. Rijeka ist ein Zentrum der Geschichts-, Kultur- und Verkehrsvielfalt und -verbindungen. Die Verkehrsverbindungen beziehen sich auf den Hafen und den Mediterranen Korridor. Die Veranstaltung war eine ausgezeichnete Chance zur Hebung der Sicherheit und Kultur im Bahnverkehr. Aufgrund des Gesagten steht die in der Arbeit vertretene These, dass die urbane, künstlerische Intervention an Bahnobjekten in Rijeka, auf zeitgenössischen Richtlinien von Unternehmen mit sozialer Verantwortung und der nachhaltigen Entwicklung beruhen kann. In erster Linie galt es, eine Analyse des Zustands von Bahnobjekten zu machen, an denen urbane und künstlerische Interventionen möglich waren. Das sind Eisenbahnbrücken, Eisenbahnkreuzungen mit Geh-und Fahrwegen, Zäune, Strecken und Gebäude. Mithilfe der Methode des 
Beobachtens und Fotografierens des Zustands wurde eine Unterlage zur Synthese von erworbenen Informationen und Erkenntnissen erarbeitet. Es wird erwartet, dass Präventionsaktivitäten im Eisenbahngebiet Rijeka durchgeführt werden und die Zahl der externen Vorfällen sinkt.

Schlüsselwörter: Europäische Kulturhauptstadt, urbane Intervention, Verkehrszugänglichkeit, die Stadt Rijeka, Bahnübergänge 